\title{
PROBLEM-BASED LEARNING AND ITS EFFECT ON LEARNERS' RELATIONSHIPS
}

\author{
Petr Emanovský \\ Palacky University, Olomouc, Czech Republic \\ E-mail: petr.emanovsky@upol.cz
}

\begin{abstract}
Detailed knowledge of learners' relationships is very important for successful teacher pedagogical work in a classroom. The familiarity with the relationships is important, especially in the case of teenagers' class. All teachers should deal with the problem of learners that are out of their classmates' interest (so called isolated learners or isolates) in such class and think about possibilities to integrate them into the class. Natural idea how to do it is that of using some non-traditional learning methods, especially the methods based on working in small groups involving learners' cooperation. Problem-based learning $(P B L)$ as one of these methods with an influence on learners' relationships was a subject of the further described research. Within PBL courses, students work with classmates to solve complex and authentic problems that help develop content knowledge as well as problem-solving, reasoning, communication, and self-assessment skills. The aim of the research was to answer the question: Can the problem-based learning help to integrate isolated learners into the class? The research was realized as a pretest-posttest design for the sample of 182 learners of seventh, eighth and ninth grades of basic school. Standardized sociometric questionnaire B-3 was used to determine the number of isolated learners before and after using the problem-based learning. Consequently, using the Wilcoxon statistic test of significance, the hypothesis was verified that the number of isolates after the problem-based learning is statistically significantly lower than that of the case before using the non-traditional learning method. Accordingly, the research results justify implementation PBL into education.
\end{abstract}

Key words: problem-based learning, learners' relationships, sociometric methods, isolated learners.

\section{Introduction}

The terrible feeling of an isolated learner receiving no choices in a group of classmates, especially in the sensitive period of adolescence, can have a significant negative effect on her or his future life. To avoid this unpleasant feeling and try to integrate the teenager back into the class team, there was tried to find some means, method or form of work which would contribute to the integration. After some experience with work of small groups of learners, the method of problem-based learning (PBL) was chosen for this purpose. It is fair to assume that PBL could contribute to the inclusion of learners standing at the edge of class to the class group. In order to ascertain the correctness of the assumption, the following research was conducted.

\section{Sociometry as the Means of Learners Relationships Research}

Sociometry represents a quantitative method for measuring of social relationships in a small group. It was developed by the psychotherapist J. L. Moreno in his studies of the relationship between social structures and psychological well-being (Moreno, 1953). One of the important means in sociometry is the sociogram, a systematic method for graphically representing individuals as points/nodes and the relationships between them as lines/arcs (McIntyre, 2003). The graphically representing is based on special sociometric questionnaire detecting learners' positive and negative choices in the class. Sociometry and sociograms are very important tools for teacher's behaviour management in the class collective. They provide a wealth of information about classroom friendship and interaction patterns, 
Petr Emanovský. Problem-based learning and its effect on learners' relationships

PROBLEMS

OF EDUCATION

IN THE $21^{\text {st }}$ CENTURY

Volume 63, 2015

54

and they can be very useful for the teacher when he/she is planning seating arrangements or work-group composition. The results of sociometric research can be applied to help make positive changes in behaviour in a classroom setting (Sherman, 2002). The sociograms help identify various groups of learners. The pattern of choices can show a star (that is someone that receives the most choices), a rejectee (he or she that receives no positive choices and a number of negative choices); everyone else is a member (receiving some positive and perhaps some negative choices) and an isolate (someone receiving no choices). Sociometry is based on the fact that people make choices in interpersonal relationships. Whenever people gather, they make choices where to sit or stand; choices about who is perceived as friendly and who not, who is central to the group, who is rejected, who is isolated (McIntyre, 2003). Sociometry can be seen as a way of measurement of the relationships between people in a social setting. It is undertaken to reveal information about individuals in their relationship to groups, in the context of their mutual activities. In education, sociometric assessment is a valuable means by which the teacher can determine the relationships of individual learners to other ones within the class. It also allows the teacher to track the roles which the learners play in mutual relationship within the classroom, identifying for example the popular children who are the centre of attention, and the neglected children who are overlooked by the majority of their peers (Hoffman, 2001).

Sociometric questionnaire is the most important and basic technique giving sociometry information. Using the questionnaire can be found out the positive choices in the group, which are sympathy, preferences, attractions, and also the negative choice - rejection. The positive choices are detected more often. The sociometric questionnaire contains usually one or more questions that allow all members of a social group to vote of the partners for certain situations or joint activities. The sociometric questionnaire is set mostly in writing form. Content of the questions depends on the specific objectives of the sociometric research. The questionnaire B-3 by Richard Braun can be also included among the sociometric questionnaires (Braun, 2012). It uses a rating scale for two factors - influence and popularity, which are supplemented by verbal reasoning of the assessments. The questionnaire is professionally standardized for the population in the Czech Republic. The questionnaire B-3, which is designed for sociometric analysis of learners of $4^{\text {th }}-9^{\text {th }}$ grade at basic school was used. The obtained data are usually processed in several ways - using matrix analysis, sociogram and calculation of sociometric indexes (Hoffman, 2001). Using the freeware "Sociogram" for creating the sociograms the number of isolates was determined (Table 1).

\section{Problem-based Learning as a Support of Isolated Learners}

Problem-based learning (PBL) is the learning method that places students at the center of the learning process. It is widely used to replace the traditional teaching method in which the teacher, who is the center, strictly follows the teaching plan and the teaching is mostly lecture-based. The problem-based learning model of Howard Barrows was developed in medical education in the early 1970 's and since that time it has been adopted in an increasing number of other areas of education (Barrows, 1985). The teacher leads the students to the learning that they desire or the learning following the problem objectives (Barrett, 2010). Problem-based learning is a student-centered learning format, in which learners learn about a subject through the experience of problem solving. PBL represents an educational approach where the problem comes first, and learning is conducted in a context (Yew, E. H. J. \& Schmidt, H. G., 2011). The defining feature of PBL is that it reverses the traditional approach to teaching and learning. The idea is that the starting point for learning should be a problem that the learner wishes to solve. The aim, however, is not primarily to solve the problem, but rather to get students themselves to identify and search for the knowledge that they need to obtain in order to approach the problem (Hmelo-Silver \& Barrows, 2006).

Collaborative problem-solving groups are a key feature of PBL. One assumption of PBL is that the small group structure helps distribute the cognitive load among the members of the 
group, taking advantage of group members' distributed expertise by allowing the whole group to tackle problems that would normally be too difficult for each student alone (Pea, 1993; Salomon, 1993). At the beginning, the students meet the problem "cold", they do not know what the problem is until it is presented. They discuss the problem, generating hypotheses based on whatever experience or knowledge they have, identifying relevant facts in the case, and identifying learning issues. The learning issues are topics of any sort, which are deemed of potential relevance to this problem and which the group feels they do not understand as well as they should (Savery \& Duffy, 2001). Note that there are no pre specified objectives presented to the students. The students generate the learning issues (objectives) based on their analysis of the problem. After the discussion, the students all engage in self directed learning. There are no assigned texts. Rather the students are totally responsible for gathering the information from the available library and computer database resources.

Working in groups, learners identify what they already know, what they need to know, and how and where to access new information that may lead to solution of the problem. The role of the teacher (known as the tutor in PBL) is to facilitate learning by supporting, guiding, and monitoring the learning process. The tutor must build students ${ }^{6}$ confidence to take on the problem, and encourage the students, while also stretching their understanding. The constructs for PBL are very different from traditional classroom/lecture learning. Problem-based learning is an instructional model that involves students in research of compelling problems that culminate in authentic problem solution (Hmelo-Silver, 2004). PBL, in contrast to the traditional frontal learning, is more inductive: students learn the content as they try to address a problem.

A further benefit of PBL is the increased collaboration amongst learners. This leads to less individualism and greater opportunities for peer learning. Barrett (2010) highlights, this method of group learning brings a shift from an individual's knowledge and control to group knowledge and group control. Due to the collaborative nature of a PBL environment, students are more likely to risk making contributions. This should lead to the development of increased self-esteem among learners and is a further argument in favour of this strategy.

The described above attributes of PBL justify us to suppose that implementation PBL into education could have positive effect on learners' relationships.

\section{Research Question and Hypothesis}

The following research question was formulated for the research:

Does the problem-based learning help isolated learners to integrate into the class collective?

The research hypothesis was formulated according to the research question:

The problem-based learning helps isolates with integration into the class more than the frontal learning.

Subsequently, the following null and alternative hypotheses were formulated to verify the research hypothesis:

$H_{0}$ : There is no statistically significant difference between the number of isolates within the frontal learning and within the problem-based learning.

$H_{A}$ : There is statistically significant difference between the number of isolates within the frontal learning and within the problem-based learning.

\section{Methodology of Research}

\section{General Characteristic of the Research and Respondents}

The research was realized as a single-group pretest-posttest design in standard conditions at basic school. According to the current situation, the sample of 182 learners of seventh, eighth and ninth grades, was available. Sociometric questionnaire B-3 was used to determine 
Petr Emanovský. Problem-based learning and its effect on learners' relationships

PROBLEMS

OF EDUCATION

IN THE $21^{\text {st }}$ CENTURY Volume 63,2015

the number of isolates before using the problem-based learning. The first questionnaire was submitted to the learners of the research group at the end of September 2014 after the previous one-month period of using classical frontal learning without any problem-based method in the classes. According to the initial sociometric results, working groups for PBL containing approximately the same number of isolates were created. The same sociometric questionnaire was submitted to the learners after application PBL. Consequently, using the Wilcoxon statistic test of significance, the hypothesis about statistical significance of difference between the number of isolates before and after the problem-based learning was tested.

\section{Instrument and Procedures}

The professionally standardized sociometric questionnaire B-3 by Richard Braun (Braun, 2012) was used to determine the number of isolates before and after using the problem-based learning. This questionnaire was chosen because it allows an easy computer processing in the form of class hierarchy, where is easy to recognize the names of children that represent the isolates. Moreover, the sociogram of positive relations as well as the sociogram of negative relations is given. Special attention was paid to such isolates that were labeled with the same order number in the sociogram and in the class hierarchy. If a positive relation from an isolate to a learner of the rest of class is found, these two learners will be assigned to one working group with the intention of strengthening of positive linkages.

Based on subsequent computer data processing of the first questionnaire, the working groups for the problem solving were created. The PBL took place in such distributed classes in the following almost one-month period. The classes did not mix each other during this period and the learners worked in small groups containing approximately the same number of isolates. The sociometric questionnaire B-3 was done by the learners after the "PBL period" again. The names of the isolated learners were obtained from the class hierarchy based on the following computer processing of the second questionnaire. The number that represents the position in the class hierarchy is obtained summing all positive options and substracting all negative ones. The „sociometric stars" have the most points and the isolates have the fewest points.

\section{Statistical Data Analysis}

The non-parametric statistical Wilcoxon test for two dependent samples was used to test the null hypothesis. This test is usually used in the case of repeated measurements of the same objects. The advantage of the test is that it reveals small differences between the measurements (McMillan \& Schumacher, 2010). The data processing was done using the software Statistica, version 12.

\section{Results of Research}

\section{Sociometric Results}

The following table shows the sociometric results connecting with the number of isolates in the classes obtained from the sociometric questionnaire.

Table 1. Sociometric results - number of isolates.

\begin{tabular}{llllllllll}
\hline & 7.A & 7.B & 8.A & 8.B & 8.C & 9.A & 9.B & 9.C & $\boldsymbol{\Sigma}$ \\
\hline Number of learners in the class & 21 & 22 & 25 & 22 & 23 & 25 & 24 & 20 & 182 \\
\hline Number of isolates before PBL & 6 & 8 & 9 & 10 & 8 & 8 & 8 & 6 & 63 \\
\hline Number of isolates after PBL & 3 & 6 & 6 & 11 & 6 & 5 & 4 & 6 & 47 \\
\hline
\end{tabular}


The difference between number of isolates before and after using PBL is evident, but the crucial question about its statistical significance demands the statistical testing of null hypothesis $H_{0}$.

Table 2. Data for Wilcoxon test.

\begin{tabular}{|c|c|c|c|c|c|c|}
\hline \multirow{2}{*}{ Class } & \multicolumn{2}{|l|}{ Number of isolates } & \multirow{2}{*}{ Differences } & \multirow{2}{*}{$\begin{array}{l}\text { Differences } \\
\text { order }\end{array}$} & \multirow{2}{*}{+} & \multirow{2}{*}{ - } \\
\hline & Before using PBL & After using PBL & & & & \\
\hline 7. A & 6 & 3 & 3 & 5 & 5 & \\
\hline 7. B & 8 & 6 & 2 & 2.5 & 2.5 & \\
\hline 8. A & 9 & 6 & 3 & 5 & 5 & \\
\hline 8. B & 10 & 11 & -1 & 1 & & 1 \\
\hline 8. C & 6 & 6 & 0 & - & - & - \\
\hline 9. A & 8 & 5 & 3 & 5 & 5 & \\
\hline 9. $B$ & 8 & 4 & 4 & 7 & 7 & \\
\hline 9. C & 8 & 6 & 2 & 2.5 & 2.5 & \\
\hline
\end{tabular}

Using the results from the Table 2, one can compute the value of Wilcoxon test criterion $T=1$. Since the table value of the criterion $T_{0.05}(7)$ for significance level $\alpha=0.05$ and for 7 pairs is equal to $2>1$, the null hypothesis $H_{0}$ is rejected. The result can be confirmed by computing of $p$-value as well. Using software Statistica $12, p=0.02799<0.05$ can be obtained. It means that, for this significance level, there exists statistically significant difference between the number of isolates after the frontal learning and that of after the problem-based learning.

\section{Discussion}

The sociometric results that have been obtained using the questionnaire represent very valuable source of information about learners ' relationships. Sociometric stars, isolates as well as individuals at risk - potential victims of aggressors and aggressors themselves can be identified using the results. Class potential is also described by responses of learners connected with their positions in the class, so one can find out those, who are not comfortable in the classroom. Class positions hierarchy is built from several outputs of the questionnaire, and therefore it can be suitably used as a basis for intervention in the class. Sociometric stars have the largest radius in the classroom, their views are respected, and so they can streamline the educational intervention of the teacher. The rejected individuals can be also found out from the results of the questionnaire. They are the easiest victims of the class bullying and the teacher would be interested to know how they are satisfied in the class collective. The tendency to be victimized by bullies has been commonly associated with low self-esteem, shyness and feeling of isolation (O'Moore \& Kirkham, 2001). In the case of negative feelings of the learner, it is necessary to find out the cause and try to change his/her position. In the case of the isolates, it is necessary to try to integrate them into the class collective.

Hall (1994) stresses the importance of using effective group work practice as a method to improve social relational and emotional development, focusing attention not only on the content of the group work activity, but also on the process and interpersonal sensitivity gained through typical procedures (Bliss et al., 1995; Curry \& Bromfield, 1998). A social relational approach necessarily focuses upon the interpersonal (as opposed to individual) development and uses the whole class as an inclusive site for development of group work. This approach is modelled on the development of close relationships such as attachment, within which trust, dependence and 
Petr Emanovský. Problem-based learning and its effect on learners' relationships

PROBLEMS

OF EDUCATION

IN THE $21^{\text {st }}$ CENTURY

Volume 63,2015

58

responsibility (Ainsworth, Stayton \& Bell, 1974) establish the bases for further relationships, social and cognitive development. Studies presented by Hall and by Kutnick and Manson show that a social relational approach for children has positive effects not only on their social capacities, but also on their (cognitive) learning and motivation to work with others (Kutnick \& Manson, 1998; Hall, 1994).

Sainsbury and Walker (2009) have found a more complex relationship between friendship and productivity of collaboration. Members of the „friends“ group demonstrated significantly greater competitive behaviours towards each other than members of the ,acquaintances“ group, with the result that their friendships began to deteriorate over the study period. Individuals within the „friends" group were primarily motivated by the need for personal achievement, particularly in examinations, which was manifest in a range of behaviours towards each other and in relation to the activities in which they participated. Individual and collective motivation thus mediated qualitative differences in the productivity of collaboration and extent of learning (Sainsbury \& Walker, 2009). These findings contribute to a deeper understanding of the interactions between individual and collective behaviours, motivations and outcomes.

The crucial problem of sociometric methods is the question of their reliability and validity. One early review (Mouton et al. 1955) indicated some of the limitations of sociometric procedures from the point of view of the stability of measures. Among other problems, the stability of the measuring instrument is confounded with the stability of persons and social structures. Validity is especially difficult to assess in sociometry, since the sociometric indexes are so often seen as the criteria to be predicted. Intrinsically, sociometric information represents the objective depicting of the situation on the basis of the most relevant judges - those with whom one participates. Thus, there has been some tendency to emphasize the prediction of sociometric status on the basis of other characteristics rather than to use sociometric status to predict other variables (Gresham, F. M. \& Stuart, D., 1992). Sociometric procedures have been incorporated into many different types of studies. For example, in small group research one of the common types of information collected in post-meeting questionnaires is the set of sociometric ratings on criteria relevant to the group participation. On this score, it should be emphasized that sociometric procedures as classically defined have tended to merge with more general procedures for obtaining peer ratings and rankings. The structure of self rankings and peer rankings has been systematically explored by various researchers, with some convergence on the types of content involved and some crystallization of information about the stability of measures (Borgatta, 1964). Content corresponding to that initially identified by Jennings (1947) with task and with social concerns has continued to be central, but other concepts have also been found to recur in analyses. Sociometric procedures have also been important to the development of several other research areas. An extensive review of this research literature (Glanzer \& Glaser, 1961) has suggested the limitations of such approaches and has placed them in their historical context. Sociometric techniques remain pervasive in the social sciences, having relevance to personality research, small group research, analysis of networks of communication and group structures, and to special topics such as the reputational study of social status in the community and the study of segregation patterns.

Of course, problem-based learning is not the only one way to improve the learners' relationships in the classroom. It is a likelihood that using another suitable modern learning methods is possible to improve learners' relationships as well. As appropriate methods that could have similar positive effect on learners' relationships seem to be also project-based learning (Baranoková, 2012; Grecmanová \& Urbanovská, 1997; Henry, 1994), cooperative learning (Cowie, H. \& Rudduck, J., 1988; Kasíková, 1997; Trabalíková, 2011), collaborative learning (Kay, 1992; Ho ek, 2001) or inquiry-based learning (Kirschner, Sweller \& Clark, 2006). A comparison of the modern teaching methods in context of learners' relationships improving could be an interesting topic for a further research. 


\section{Conclusions}

The research results showed that the number of isolates within the frontal learning and problem-based learning is statistically significantly different. The number of isolates occurring in the class before implementation of the problem-based learning, i.e., within the classical frontal learning, is higher than after using PBL. One can say that the problem-based learning represents an effective means for integration of isolates to the class collective. Problem-based learning gets more positive, and therefore we consider it appropriate to implement into education. However, it is an illusion that PBL is the only way of including isolates into the class, but the results of the research have confirmed that it is very useful help for the marginalised children to be incorporated into their team.

\section{Acknowledgements}

This work was supported by the Palacky University project "Mathematical Structures" IGA PrF 2014016 and 2015010.

\section{References}

Ainsworth, M., Bell, S., \& Stayton, D. (1974). Infant-mother attachment and social development: 'socialisation' as a product of reciprocal responsiveness to signals. In M. Woodhead, R. Carr \& P. Light (Eds.) Becoming a Person. London: Routledge.

Baranoková, E. (2012). Projektové vyučování jako pomoc dětem na okraji třídy (Project-based learning as help for marginalized learners). (Diploma Thesis), Olomouc: Palacky University.

Barrett, T. (2010). The problem-based learning process as finding and being in flow. Innovations in Education and Teaching International, 47 (2), 165.

Barrows, H. S. (1985). How to design a problem-based curriculum for the preclinical years. New York: Springer Publishing Co.

Bliss, T., Robinson, G., \& Maines, B. (1995). Developing Circle Time. London: Lame Duck Publishing.

Borgatta, E. F. (1964). The structure of personality characteristics. Behavioral Science 9, 8-17.

Braun, R. (2012). Dotazníky B-3 a B-4, představení metody a vyhodnocování (Questionnaires B-3 and $B-4$, introduction to the method and evaluation). Retrieved from: http:// spp.ippp.cz/download/ studijni-materialy/dotazniky-B3-B4.pdf.

Cowie, H., \& Rudduck, J. (1988). Cooperative learning. Traditions and transitions. London: Britannic House.

Curry, M., \& Bromfield, C. (1998). Circle time in-service training manual. Tamworth: NASEN.

Chráska, M. (2007). Metody pedagogického výzkumu (Methods of Pedagogical Research). Praha: Grada.

Glanzer, M., \& Glaser, R. (1961). Techniques for the study of group structure and behavior: 2. Empirical studies of the effects of structure in small groups. Psychological Bulletin, 58, 1-27.

Grecmanová, H., \& Urbanovská, E. (1997). Projektové vyučování a jeho význam v současné škole [Project-based learning and its importance at current school]. Pedagogika, 1, 37-45.

Gresham, F. M., \& Stuart, D. (1992). Stability of sociometric assessment: Implication for uses as selection and outcome measures in social skills training. Journal of School Psychology, 30, 223-231.

Hall, E. (1994). The social relational approach. In P. Kutnick \& C. Rogers (Eds.) Groups in Schools. London: Cassell.

Henry, J. (1994). Teaching through projects. London: Kogan Page Limited.

Hošek, D. (2001). Kooperativní a kolaborativní učení (Cooperative and collaborative learning). Retrieved from: http://it.pedf.cuni.cz/strstud/edutech/2001_Kolabor_Hosek/INDEX.HTM\#KAY

Hmelo-Silver, C. E. (2004). Problem-based learning: What and how do students learn? Educational Psychology Review, 16 (3), 235 - 266.

Hmelo-Silver, C. E., \& Barrows, H. S. (2006). Goals and strategies of a problem-based learning facilitator. Interdisciplinary Journal of Problem-Based Learning, 1.

Hoffman, C. (2001). Introduction to sociometry. Retrieved from: http://www.hoopandtree.org/sociometry. htm 
Petr Emanovský. Problem-based learning and its effect on learners' relationships

PROBLEMS

OF EDUCATION

IN THE $21^{\text {st }}$ CENTURY Volume 63, 2015

Jennings, H. H. (1947). Sociometric differentiation of the psychegroup and the sociogroup. Sociometry, 10, 71-79.

Johnson, D. W., Johnson, R. T., \& Stanne, M. E. (2000). Cooperative learning methods: A meta-analysis.

University of Minnesota, Minneapolis: Cooperative Learning Center. Retrieved from: http://www.cooperation.org/pages/cl-methods.html

Kay, A. R. (1992). Collaborative learning through computer conferencing. The Najaden Papers, New York: Springer-Verlag.

Kasíková, H. (1997). Kooperativní učení, kooperativní škola [Cooperative learning, cooperative school]. Praha: Portál.

Kratochvílová, J. (2003). Teorie a praxe projektové výuky [Theory and practice of project-based learning]. Brno: Pedagogická fakulta MU.

Kutnick, P. (2005). The effect of pupil grouping: Literature review. University of Brighton.

Kutnick, P., \& Manson, I. (1998). Social life in the classroom: Towards a relational concept of social skills for use in the classroom. In A. Campbell \& S. Muncer (Eds.) The Social Child, Hove: The Psychology Press.

McIntyre, T. (2003). Sociograms. Retrieved from: http://maxweber.hunter.cuny.edy/pub/eres/EDSPC715 MCINTYRE/Sociogram.html

McMillan, J. M., \& Schumacher, S. (2010). Research in education. New Jersey: Pearson Education.

Moreno, J. L. (1953). Who shall survive? Beacon House, Inc.: Foundations of Sociometry, Group Psychotherapy and Sociodrama.

Mouton, J. S., Blake, R. R., \& Fruchter, B. (1955). The reliability of sociometric measures. Sociometry, $18,7-48$.

O'Moore, M., \& Kirkham, C. (2001). Self-esteem and its relationship to bullying behavior. Aggressive Behavior, 27, $269-283$.

Pea, R. D. (1993). Practices of distributed intelligence and designs for education. In Salomon, G., and Perkins, D. (Eds.), Distributed Cognitions: Psychological and Educational Considerations. New York: Cambridge University Press, 47-87.

Sainsbury, E., \& Walker, R. (2009). Motivation, learning and group work - the effect of friendship on collaboration. In UniServe Science Proceedings. University of Sydney, 118-124.

Salomon, G. (1993). No distribution without individual cognition: A dynamic interactional view. In Salomon, G., and Perkins, D. (Eds.), Distributed Cognitions: Psychological and Educational Considerations, New York: Cambridge University Press, 111-138.

Savery, J. R., \& Duffy, T. M. (2001). Problem based learning: An instructional model and its constructivist framework. Report No. 16-01. Indiana University: Center for Research on Learning and Technology.

Sherman, L. (2002). Sociometry in the classroom. Retrieved from: http://www.users.muohio.edu/ shermalw/sociometryfiles/socio arehtmlx\#what.

Sociogram, freeware. Retrieved from: http://www.phenotyping.com/sociogram/mSociogram.html

Thomas, J. W. (1998). Project-based learning: Overview. Novato, CA: Buck Institute for Education.

Trabalíková, J. (2011). Kooperatívne vyučovanie a jeho vplyv na klímu triedy v 5. roč. ZŠ (Cooperative learning and its effect on class climate at $5^{\text {th }}$ grade of basic school). PEDAGOGIKA.SK, 2 (1), $36-52$.

Yew, E. H. J., \& Schmidt, H. G. (2011). What students learn in problem-based learning: A process analysis. Instructional Science, 40 (2), 371-395.

\section{Appendix. Sociometric Questionnaire B-3}

1. Among my friends in our class belong:

1 . $3 \mathrm{~b}$.

2. $\ldots \ldots \ldots \ldots \ldots . . .2 \mathrm{~b}$.

3. $\ldots \ldots \ldots \ldots \ldots \ldots 1 \mathrm{~b}$. 
2. As a boyfriend/girlfriend I would not choose:

1. $3 \mathrm{~b}$.

2. $\ldots \ldots \ldots \ldots \ldots \ldots \ldots \ldots \ldots$ b.

3. $\ldots \ldots \ldots \ldots \ldots \ldots 1 \mathrm{~b}$.

3. I evaluate myself as follows:

a) I am always at center stage in the classroom.

b) Sometimes I participate and I am usually informed of events in the classroom.

c) A couple of times I participated in, but I do not use to be informed.

d) It seems that the class does not care about my participation too much.

e) I am not interested in the events in the classroom.

4. Answer yes - no:

In the classroom is at least one pupil who is unhappy. yes - no

Who is it?

Why is he/she unhappy?

There is someone in the class that others hurt him/her occasionally. yes - no

Who is it?

Why they hurt him/her?

It happens that I' $\mathrm{m}$ looking forward to school. yes - no

Mostly I find someone who can help me with a problem. yes - no

Common problems we deal mostly in peace. yes - no

5. Circle the number in each row that best expresses the degree of your feelings in the classroom:

$\begin{array}{lrl}\text { Feeling of security } & 1234567 & \text { Feeling of threat } \\ \text { Feeling of friendship } & 1234567 & \text { Feeling of antagonism } \\ \text { Atmosphere of cooperation } & 1234567 & \text { Atmosphere of indifference } \\ \text { Feeling of confidence } & 1234567 & \text { Feeling of distrust } \\ \text { Tolerance } & 1234567 & \text { Intolerance }\end{array}$

6. Find someone in the class that is:

Righteous

Offensive

Reliable

Unjust

Witty

Ungrateful

Always at the center of the action

Unreliable

On good terms with all

Alone

Advised by Bronislava Štepankova, Palacky University, Czechia

Received: February 09, 2015

Accepted: February 16, 2015

Petr Emanovský

PhD., Associate Professor, Department of Algebra and Geometry, Faculty of Sci-

ence, Palacky University, Olomouc, Czech Republic.

E-mail: petr.emanovsky@upol.cz

Website: http://www.upol.cz 